Original Research Article

\title{
Cost analysis study of price variation among the various brands of antiepileptics available in India
}

\author{
Nagaraja Prasad Sai ${ }^{1}$, Vedavathi H. $^{2}$
}

${ }^{1}$ Assistant Professor, ${ }^{2}$ Professor and HOD, Department of Pharmacology, Shivamogga Institute of Medical Sciences, Shivamogga, Karnataka, India

Received: 12 December 2016 Received: 14 December 2016 Accepted: 03 January 2017

\section{*Correspondence to: \\ Dr. Nagaraja Prasad Sai, \\ Email: \\ drnagarajprasad@gmail.com}

Copyright: (C) the author(s), publisher and licensee Medip Academy. This is an openaccess article distributed under the terms of the Creative Commons Attribution NonCommercial License, which permits unrestricted noncommercial use, distribution, and reproduction in any medium, provided the original work is properly cited.

\begin{abstract}
Background: One of the major cost that the patient has to bear during therapy is medication cost Different brands of the same mediations are available leading to considerable price variation. This can affect medication compliance by the patient. The present study was undertaken to evaluate the variation in costs of antiepileptic's available in India.

Methods: Cost of all antiepileptics (tablets/capsules) available in India was obtained from CIMS July to Oct 2016 and from IDR Vol XXII issue No 3, 2016. The percentage cos ratio and percentage variation in cost were calculated and compared.

Results: The highest cost ratio and percentage price variation was found with carbamazepine $200 \mathrm{mg}$ (1:12 and 1100) followed by acetazolamide $250 \mathrm{mg}$ (1:11.38 and 1037.68). Other significant cost variations $(>100 \%)$ were seen with carbamazepine $100 \mathrm{mg}$, phenobarbital $30 \mathrm{mg}$, divalproex sodium $25 \mathrm{mg}$, lorazepam $1 \mathrm{mg}$, clonazepam $1 \mathrm{mg}$ and valproic acid $500 \mathrm{mg}$. Lowest percentage cost variation was seen with oxcarbazepine $450 \mathrm{mg}$ (1.09), lacosamide $50 \mathrm{mg}$ (2.56), pregabalin 50mg (3.51) and zonisamide 50mg (4.21).

Conclusions: The Government of India regulates prices of essential drugs through Drug Price Control Order (DPCO) and this is implemented by National Pharmaceutical Pricing Policy (NPPA). However nearly $80 \%$ of medications donot fall into this category. This leads to considerable economic burden on poor patients. There is still considerable price difference among various brands of antiepileptic available in India. The Government of India should take a firm decision and implement them with regard to pricing of medications so as to make them more affordable, especially for diseases which require long term treatment such as epilepsy.
\end{abstract}

Keywords: Cost analysis, antiepileptics, Percentage cost variation, Pharmacoeconomics

\section{INTRODUCTION}

Seizure is derived from the 5th century Latin word "seiz" meaning of which is to "take possession of" and epilepsy is derived from the Greek word "epilepsia" which also means to "seiz". ${ }^{1}$ Epilepsy is defined as recurrent (two or more) epileptic seizures unproved by any immediate identifiable cause with a lifetime prevalence of $1.5-5 \%$. $^{2}$ Worldwide it has been shown to affect 50 million people with nearly $90 \%$ of them living in developing countries. Prevalence ranges from 5-10 per 1,000 in most countries and it is slightly higher in developing countries. The incidence ranges from 24-70 per 1, 00,000 population. The overall lifetime risk of developing epilepsy is said to be $3 \%$ up to 80 years. It is more common in extremes of age and men are slightly more commonly affected than women. ${ }^{1,3}$

There are various antiepileptics available which include sodium valproate, valproic acid, phenytoin sodium, carbamazepine, lamotrigine, ethosuximide, gabapentin, vigabitrin, diazepam, clobazam, lorazepam, phenobarbitone, topiramate, tiagabine, fosphenytoin, leviteracetam, pregabalin, primidone etc. ${ }^{4}$

India is still a developing country and majority of its population are middle income families or come from a poor socioeconomic background. According to the 
planning commission report $29.5 \%$ of Indians 1.21 billion people live below poverty line. ${ }^{5}$ With epilepsy being very common in developing countries it becomes a huge burden on people living in lower socioeconomic strata to buy medicines especially if they have to be taken for prolonged periods of time.

Physician tends to prescribe more costly drugs when compared to the generic versions which are much cheaper and easily available. This tends to increase the cost of medications unnecessarily which in turn may manifest as non-compliance or decreased compliance especially once the seizure control is achieved through adequate medication. This may manifest as resurgence of seizure episode.

Compliance is the extent to which the patient adheres to the physicians instructions in all aspects including medication therapy. ${ }^{6}$ Patient related non-compliance can severely affect seizure recurrence. Non-compliance is a significant problem with anticonvulsants and is a potent cause of poor control of seizures. ${ }^{2}$ The physician should consider the drug side effect profile, drug dosing schedule and cost whenever selecting an anti-epileptic drug. ${ }^{3}$ There is a gross variation in the cost of different brands of same generic drugs available in India. Increase in the patient medication cost was found to be associated with decreased adherence to prescription medication. ${ }^{7}$ According to Kaiser family foundation survey in 2015 nearly $25 \%$ of those taking prescription medications have reported that they have not filled a prescription in past 12 months due to cost concerns. ${ }^{8,9}$ In order to manage costs, many patients on long term therapy fail to take medicines regularly or skip doses or reduce doses or delay filling prescriptions. $^{10}$

Cost analysis is a type of pharmacoeconomic evaluation in which comparison of costs of two or more alternative medication is made without regard to outcome. ${ }^{11,12}$ Various studies conducted in past show a wide variation in prices of cost of branded and generic versions of same drug. ${ }^{13,14}$

Hence the present study was undertaken to evaluate the price variation amongst the different brands of antiepileptic's available in India.

\section{METHODS}

1. Price in Indian rupees(INR) of antiepileptic drugs manufactured by different pharmaceutical companies in India, in the same strength were obtained from Current Index of Medical Specialties(CIMS) July to October 2016 and from Indian Drug Review Vol XXII Issue No 3, 2016.

2. The cost of 10 tablets/capsules was calculated.

3. The cost ratio, ratio of cost of costliest to cheapest brand of the same generic drug was estimated. This gives an estimate, how many times the costliest brand costs more than the cheapest one in each generic group.

4. Percentage cost variation was calculated as follows: $\%$ cost variation $=$ (maximum cost-minimum cost/minimum cost) $\mathrm{X} 100$

5. Fixed dose combinations (FDCs), pediatric preparations were not analyzed in the present study.

\section{RESULTS}

The study shows that there is a gross variation in the prices of different brands of same antiepileptic drug available in Indian market. The highest cost ratio (1:12) and percentage cost variation (1100) was found for carbamazepine tablet $200 \mathrm{mg}$, followed by cost ratio (1:11.38) and percentage price variation (1037.68) for acetazolamide $250 \mathrm{mg}$ tablet.

Other significant cost variations were seen with carbamazepine 100mg tablet (1032.69), phenobarbital $30 \mathrm{mg}$ tablet (314.95), divalproex sodium $25 \mathrm{mg}$ tablet (250), lorazepam $1 \mathrm{mg}$ tablet (3.75), clonazepam $1 \mathrm{mg}$ tablet (244), valproic acid 500mg tablet (243.59\%), and phenobarbitone $60 \mathrm{mg}$ tablet (239.39). Lowest percentage cost variation was found with oxcarbamazepine $450 \mathrm{mg}$ tablet (1.09), lacosamide 50mg tablet (2.56), pregabalin $50 \mathrm{mg}$ tablet (3.51) and zonisamide 50mg tablet (4.21).

\section{DISCUSSION}

Medicine pricing assumes significance especially in a developing country like India. This situation is further complicated by the number of branded formulation for different drugs. ${ }^{15}$ The price of medicine in India is regulated by Drug (Price Control) Order (DPCO) issued by Government of India through the official gazette. ${ }^{16}$ This in turn is implemented by National Pharmaceutical Pricing authority (NPPA). ${ }^{17}$ This helps in regulation of prices of various essential drugs mentioned in the National Essential Drug List. ${ }^{18}$ However it was found in various studies that the prices vary considerably between different brands of the same drug. The price variation can be due to different factors like cost of the ingredients, methods used in preparation of drug, procurement mechanisms in public and private pharmacies. In the government sector procurement is made directly from pharmaceutical manufacturers recognized by the government or from government established manufacturing facilities, whereas in the private sector there is multi-layered procurement mechanism leading to increase in cost of price of medicine brought by consumer (patient). A study by Singal et al showed that private retail pharmacy margins can be $25-30 \%$ for a branded medicine and this may further increase to 201 to $1016 \%$ for branded generic medicines. ${ }^{19}$ All these factors considerably increase the burdenof treatment costs on the common people in India. The price variation assumes significance when the cost ratio reaches more than 2 and percentage price variation is more than 100 . 
Table 1: Drug costs, cost ratio and percentage cost variation of antiepileptic available in India.

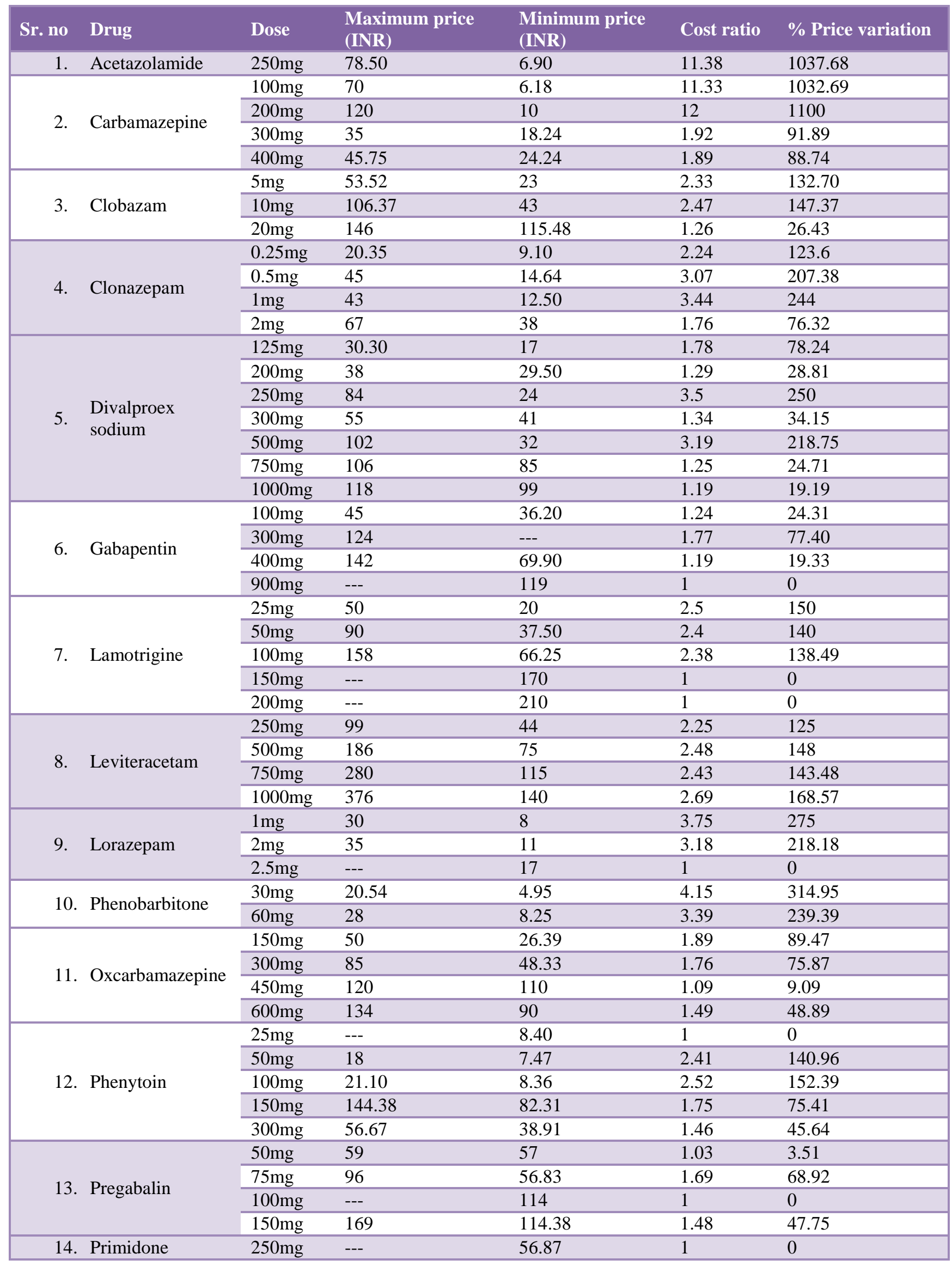


Table 1: Drug costs, cost ratio and percentage cost variation of antiepileptic available in India.

\begin{tabular}{|c|c|c|c|c|c|c|}
\hline Sr. no & Drug & Dose & $\begin{array}{l}\text { Maximum price } \\
\text { (INR) }\end{array}$ & $\begin{array}{l}\text { Minimum price } \\
\text { (INR) }\end{array}$ & Cost ratio & $\%$ Price variation \\
\hline \multirow{3}{*}{15.} & \multirow{3}{*}{ Topiramate } & $25 \mathrm{mg}$ & 38 & 19 & 2 & 100 \\
\hline & & $50 \mathrm{mg}$ & 85 & 36 & 2.36 & 136.11 \\
\hline & & $100 \mathrm{mg}$ & 158 & 108 & 1.46 & 46.30 \\
\hline \multirow{7}{*}{16.} & \multirow{7}{*}{ Valproic acid } & $200 \mathrm{mg}$ & 46 & 19.50 & 2.36 & 135.90 \\
\hline & & $250 \mathrm{mg}$ & 55 & 49 & 1.12 & 12.24 \\
\hline & & $300 \mathrm{mg}$ & 56 & 25.90 & 2.16 & 116.22 \\
\hline & & $400 \mathrm{mg}$ & --- & 79 & 1 & 0 \\
\hline & & $500 \mathrm{mg}$ & 134 & 39 & 3.44 & 243.59 \\
\hline & & $750 \mathrm{mg}$ & --- & 49.90 & 1 & 0 \\
\hline & & $1000 \mathrm{mg}$ & --- & 59.90 & 1 & 0 \\
\hline \multirow{3}{*}{17.} & \multirow{3}{*}{ Zonisamide } & $25 \mathrm{mg}$ & --- & 32 & 1 & 0 \\
\hline & & $50 \mathrm{mg}$ & 59.40 & 57 & 1.04 & 4.21 \\
\hline & & $100 \mathrm{mg}$ & 160 & 87.79 & 1.82 & 82.25 \\
\hline \multirow{4}{*}{18.} & \multirow{4}{*}{ Lacosamide } & $50 \mathrm{mg}$ & --- & 45 & 1 & 0 \\
\hline & & $100 \mathrm{mg}$ & 80 & 78 & 1.03 & 2.56 \\
\hline & & $150 \mathrm{mg}$ & --- & 120 & 1 & 0 \\
\hline & & $200 \mathrm{mg}$ & --- & 150 & 1 & 0 \\
\hline
\end{tabular}

In our present study we found the price variation to be greater than $100 \%$ for drugs like carbamazepine $200 \mathrm{mg}$ (1100), acetazolamide 250mg (1037.68), carbamazepine $10 \mathrm{mg}$ tablet (1032.69), phenobarbital 30mg (314.95) and divalproex sodium $250 \mathrm{mg}$ (250). The lowest price variation was seen among oxcarbamazepine $450 \mathrm{mg}$ (1.09), lacosamide 50mg (2.56), pregabalin 50mg tablet (3.51) and zonisamide 50mg (4.21).

In one study by Laxman Wagh et al it was shown that leviteracetam (conventional 250mg tablet) had a cost variation of $1034.09 \%$ which was found to be not true, because as per our study percentage cost variation with leviteracetam $250 \mathrm{mg}$ tablet was $125 \% .^{20}$ In our study the highest percentage cost variation was seen with carbamazepine $200 \mathrm{mg}$ (1100\%).

This high variation in prices of medicines can affect patient's compliance. Also medicine cost is not the only cost which the patient has to bear upon him, there are other costs that the patient has to cope with like the transportation costs, loss of income etc. which are however not much under control of the patient. But the medicine cost can be controlled by ensuring that the physician has awareness about cost of medication he is prescribing. $^{21}$

Also questions are raised about the quality of generic medicine compared to branded formulations. But we must keep in mind the fact that all drug manufacturers are obliged to follow and maintain Good Manufacturing Practices (GMPs) at their establishments as per guideline laid down by Drugs and Cosmetics Act 1945. GMPs guidelines cover all stages of drug production process and the quality standards layed down have a very stringent verification process before issuing a GMP certificate to the drug manufacturer. ${ }^{22}$ In a study by Singal et al comparing branded and branded generic versions of drugs has found that both versions of drugs are identical in quality and that they fulfilled all criteria prescribed by regulatory authorities. ${ }^{19}$

Some measures to decrease price variation of drugs is to use the special authority power of government to cap the prices of non-scheduled drug (not in the NLEM) as nearly $80 \%$ of medicines are not covered by price control order and secondly to provide incentives to drug manufacturers through measures like tax exemptions. ${ }^{23,24}$

\section{CONCLUSION}

$\mathrm{T}$ There is a lot of price variation among the various brands of antiepileptic's available in India. This can lead to partial or noncompliance by the patient as treatment of epilepsy is prolonged in nature. The regulatory authorities should use their jurisdiction in controlling the price variation of such branded drugs. Also the physician should be aware of such differential pricing of medicines when prescribing drugs. Also the consumer (patient) should be educated about branded drugs and generic formulations and his socioeconomic status should be taken into consideration while prescribing medications in order to improve patient compliance especially for diseases requiring long term treatment.

\section{ACKNOWLEDGEMENTS}

The authors are thankful to the Director/Dean for his support in publishing this article. 
Funding: No funding sources

Conflict of interest: None declared

Ethical approval: Not required

\section{REFERENCES}

1. Thomas SV. Epilepsy. In: Munjal Y P Ed in Chief. API-Textbook of Medicine. The Association of Physicians of Medicine. $9^{\text {th }}$ Ed Vol 2. API Mumbai; 2012:1371-1383.

2. Perkin GD. Epilepsy in later childhood and adulthood. In: Warrell D A, Cox T M, Firth J D ed. Oxford Textbook of Medicine. $5^{\text {th }}$ Ed Vol 3. Oxford University Press, Oxford; 2010:4810.

3. Bope ET, Kellerman RD. Conn's Current Therapy. Elsevier Saunders, Philadelphia; 2013:646-653.

4. Tripathi KD. Essentials of Medical Pharmacology. 7th ed. Jaypee Brothers Medical Publishers (P) Ltd, New Delhi; 2013:412.

5. Planning Commission Report. Government of India 2014. Available at http://www.planningcommission.nic.in/reports/genre p/por_rep0707.pdf.

6. Cramer JA, Roy A, Burrell A, Fairchild CJ, Fuldeore MJ, Olendorf DA et al. Medication compliance and persistence: terminology and definitions. Value in Health. 2008;11:44-7.

7. Eaddy MT, Cook CL, O’Day K, Burch SP, Cantrell CR. How patient cost-sharing trends affect adherence and outcomes: A literature review. $\mathrm{P}$ and $\mathrm{T}$. 2012;37:45-55.

8. Kaiser Family Foundation. 2015. Available at https:// www.kff.org./health-costs/report/the-burden-ofmedical-debt-results-from-the-kaiser-familyfoundationnew-york-times-medical-bills-survey/.

9. Kennedy J, Morgan S. Cost related prescription nonadherence in the United States and Canada: A system level comparison using the 2007 International Health Policy Survey in Seven Countries. Clin Ther 2009;31(1):213-9.

10. Cohen RA, Kirzinger WK, Gindi RM. Strategies used by adults to reduce their prescription costs. NCHS Data Brief. 2013;(119):1-8.

11. Ahuja J, Gupta M, Gupta AK, Kohli K. Pharmacoeconomics. Natl Med J India. 2004;17:803.

12. Sanchez LS. Pharmacoeconomics: Principles, methods and applications. In: Dipiro JT, Talbert RL, Yee GC, Matzke GR, Wells BG, Posey ML Eds. Pharmacotherapy: A pathophysiological approach. 7th Ed. McGraw Hill; New York; 2008:1-2.

13. Das SC, Mandal M, Mandal SC. A critical study on availability and price variation between different brands: impact on access to medicines. Indian $\mathrm{J}$ Pharm Sci. 2007;69(1):160-3.

14. Chawan VS, Gawand KV, Badwane SV. Cost analysis of oral hypolipidaemic agents available in India. Int J Basic Pharmacol. 2014:3:954-7.

15. Rataboli PV, Garg A. Confusing brand names: Nightmare of medical profession. J Postgrad Med. 2005;51:13-6.

16. Gazette of India-Extraordinary Part II-Sec 3(ii).Drug Price Control Order. New Delhi, Ministry of Chemicals and Fertilizers. Department of Pharmaceuticals (National Pharmaceutical Pricing Authority) 2013:2:36-67. Available at http://www.nppaindia.nic.in/DPCO 2013.pdf.

17. Compendium of notified ceiling prices of scheduled drugs. National Pharmaceutical Pricing Authority 2015. Available at http://www.nppaindia.nic.in/ceiling/press.

18. National List of Essential Medicines 2015. Available at http://www.cdsco.nic.in/NLEM 2015/recommendations.pdf.

19. Singal GL, Nanda A, Kotwani A. A comparative evaluation of price and quality of some branded versus branded-generic medicines of the same manufacturer in India. Indian $\mathbf{J}$ Pharmacol. 2011;43(2):131-6.

20. Wagh L, Swamy KM, Kempegowda MB. Cost variation of study of antiepileptic drugs available in India. Asian J Pharm Clin Res. 2016;9(2):64-8.

21. Frazier LM, Brown JJ, Divine GW. Can physician education lower the cost of prescription drugs? A prospective controlled trial. Ann Intern Med. 1991;115:116-21.

22. Schedule M. Good Manufacturing Practices and Requirements of premises, plant and equipment for pharmaceutical products. New Delhi. Available at http://www.cdsco.nic.in/Schedule M (GMP).pdf.

23. Nagarajan R. $80 \%$ of medicines not covered by price control order. Times of India; c2015. Available at http://timesofindia.indiatimes.com/india/80-ofmedicines-not-covered-by-price-controlorder/articleshow/26678324.cms.

24. Atal S, Atal S, Deshmankar B, Nawaz SA. Cost analysis of commonly used drugs under price control in India: assessing the effect of drug price control order on brand price variation. International $\mathrm{J}$ of Pharmacy and Pharmaceutical Sciences. 2016;8(4):315-21.

Cite this article as: Nagaraja PS, Vedavathi $\mathrm{H}$. Cost analysis study of price variation among the various brands of antiepileptics available in India. Int $\mathrm{J}$ Basic Clin Pharmacol 2017;6:422-6. 